\title{
Ekstraksi Daun Cocor Bebek Menggunakan Berbagai Pelarut Organik Sebagai Inhibitor Korosi Pada Lingkungan Asam Klorida
}

\author{
Tri Reksa Saputra*, Agustinus Ngatin
}

Teknik Kimia, Politeknik Negeri Bandung, Bandung 40012

INFO ARTIKEL

Diterima 18 April 2019

Disetujui 30 April 2019

Key word:

Corrosion Inhibitor

Cocor bebek

Hydrochloric Acid

\section{Kata kunci:}

Inhibitor Korosi

Cocor bebek

Asam Klorida *e-mail: tri.reksa@polban.ac.id

*Telp: 08179294177

\begin{abstract}
A B S T RACT
Research has been conducted on the extraction of cocor bebek leaves using organic solvents with various levels of solvent polarity. This is done to obtain which solvent has a corrosion inhibitor activity in the hydrochloric acid environment, where five fractions are obtained, namely n-hexane, ethyl acetate, acetone, acetic acid, and methanol. Based on quantitative analysis of cocor bebek leaf extract in variations in the polarity of solvents using a spectrophotometer with a wavelength of $511 \mathrm{~nm}$. The flavonoid content in cocor bebek leaf extract produced using acetone solvent showed the highest yield. Corrosion rate of carbon steel in $0.1 \mathrm{M} \mathrm{HCl}$ solution; 0.05M; 0.01M with the addition of cocor bebek leaf extract decreased as the concentration of extract increased and reached the lowest decrease in the addition of extracts in acetone solvent around 200 ppm with a corrosion rate of $42.18 \mathrm{mpy}$ in $0.1 \mathrm{M} \mathrm{HCl}$ solution and at an increase in extract concentration there was a decrease does not show a significant reduction in corrosion rate. For $0.05 \mathrm{M} \mathrm{HCl}$ solution and $0.01 \mathrm{~m}$ concentration showed a decrease in corrosion rate until the addition of 1500 ppm extract. The results of the extract using acetone solvent showed the corrosion rate of carbon steel in $0.1 \mathrm{M} \mathrm{HCl} \mathrm{solution;} \mathrm{0.05M;}$ and $0.01 \mathrm{M}$ lower than the extract results with other solvents (ethyl acetate, methanol, and $5 \%$ acetic acid).
\end{abstract}

\section{A B S T RAK}

Telah dilakukan penelitian mengenai ekstraksi daun cocor bebek dengan menggunakan pelarut organik dengan berbagai tingkat kepolaran pelarut. Hal ini dilakukan untuk memperoleh pelarut mana yang mempunyai aktivitas inhibitor korosi pada lingkungan asam klorida, dimana diperoleh lima fraksi yaitu fraksi n-heksana, etil asetat, aseton, asam asetat, dan metanol. Berdasarkan analisis kuantitatif ekstrak daun cocor bebek dalam variasi sifat kepolaran pelarut menggunakan alat spektrofotometer dengan panjang gelombang 511nm. Kandungan flavanoid dalam ekstrak daun cocor bebek dihasilkan menggunakan pelarut aseton menunjukkan hasil paling tinggi. Laju korosi baja karbon dalam larutan $\mathrm{HCl}$ 0,1M; 0,05M; 0,01M dengan penambahan ekstrak daun cocor bebek mengalami penurunan seiring dengan peningkatan konsentrasi ekstrak dan mencapai penurunan terendah pada penambahan ekstrak dalam pelarut aseton sekitar 200 ppm dengan laju korosi 42,18 mpy dalam larutan $\mathrm{HCl}$ 0,1M dan pada peningkatan konsentrasi ekstrak terdapat penurunan laju tidak menunjukkan penurunan laju korosi yang signifikan. Untuk larutan $\mathrm{HCl}$ 0,05M dan 0,01m konsentrasi menunjukkan penurunan laju korosi sampai pada penambahan ekstrak 1500 ppm. Hasil ekstrak menggunakan pelarut aseton menunjukkan laju korosi baja karbon dalam larutan $\mathrm{HCl}$ 0,1M; 0,05M; dan 0,01M lebih rendah dibandingkan hasil ekstrak dengan pelarut lain (etil asetat, metanol, dan asam asetat $5 \%$ ). 


\section{Pendahuluan}

Kebutuhan terhadap besi dan baja semakin bertambah sesuai dengan perkembangan dan kemajuan teknologi. Besi dan baja banyak digunakan di industri manufaktur, sebagai bahan konstruksi, kendaraan bermotor dan elektronik. Untuk menunjang kebutuhan besi dan baja di industri dibutuhkan kualitas besi dan baja yang baik. Besi atau baja karbon merupakan material yang rentan terhadap serangan korosi akibat berinteraksi dengan lingkungan, khususnya lingkungan yang korosif. Lingkungan yang korosif adalah lingkungan yang mengandung bahan korosif seperti oksigen terlarut dalam air, udara lembab, lingkungan garam, serta lingkungan asam [1]. Untuk mengendalikan korosi logam baja karbon di lingkungan korosif salah satunya dapat ditambahkan suatu inhibitor.

Korosi merupakan penurunan mutu atau destruksi dari suatu material logam akibat adanya reaksi secara kiwiawi atau elektrokimia dengan lingkungan [2]. Proses korosi logam berlangsung secara elektrokimia yang terjadi secara simultan pada daerah anoda dan katoda yang membentuk rangkaian arus listrik tertutup [3]. Beberapa upaya yang dilakukan untuk mengendalikan proses korosi logam diantaranya adalah dengan penambahan inhibitor korosi, perlindungan katodik, pelapisan pada permukaan logam, dan lainlain. Pengendalian korosi logam dengan penambahan inhibitor korosi merupakan metode yang ekonomis dan praktis dan dilakukan dalam suatu media cair [4]. Inhibitor korosi merupakan suatu zat yang dalam jumlah kecil ditambahkan ke dalam medium korosif untuk menurunkan laju korosi dengan cara memperlambat reaksi di anoda dan katoda. Inhibitor korosi merupakan bahan kimia yang berasal dari senyawa organik yang mengandung gugus dengan pasangan elektron bebas seperti fosfat, urea, fenilalanin, imidazolin, dan senyawa-senyawa amina [5]. Pada kenyataannya bahan kimia sintesis adalah bahan kimia yang berbahaya, sehingga diperlukan inhibitor korosi yang aman, bersifat biodegradable, dan mudah didapatkan, serta murah. Beberapa senyawa metabolit sekunder pada tanaman memiliki aktivitas antioksidan, yaitu golongan alkaloid, flavonoid, saponin, tanin, steroid atau triterpenoid [6]. Ekstrak daun cocor bebek (Kalanchoe pinnata) mengandung antioksidan seperti tanin, flavonoid, steroid/triterpenoid, dan saponin. Senyawa antioksidan dapat menghambat aktivitas proses oksidasi dengan mendonorkan sepasang elektronnya (suatu radikal yang memeliliki sepasang elektron) kepada suatu material, sehingga dapat dimanfaatkan sebagai inhibitor korosi dengan memberikan sepasang elektronnya ke permukaan logam Fe dan akan membentuk senyawa kompleks yang stabil dan lebih tahan terhadap korosi [3]. Senyawa antioksidan golongan steroid/triterpenoid merupakan senyawa yang larut dalam pelarut non polar, golongan alkaloid termasuk senyawa semi polar yang dapat larut dalam pelarut semi polar, dan golongan flavonoid, saponin, dan tanin merupakan senyawa yang larut dalam pelarut polar seperti metanol, etanol, etil asetat dan pelarut polar lainnya Proses ekstraksi cocor bebek dapat dilakukan menggunakan metode maserasi menggunakan metanol dan dilanjutkan menggunakan pelarut non polar untuk melarutkan senyawa golongan steroid, dan semi polar untuk melarutkan golongan alkaloid, seperti pelarut polar untuk melarutkan senyawa polar seperti golongan flavanoid dan tanin.

Larutan asam, khususnya lingkungan asam klorida merupakan lingkungan yang sangat korosif dan menyebabkan logam baja dengan cepat mudah mengalami korosi atau kerusakan dengan laju korosi yang cepat dengan adanya ion $\mathrm{H}^{+}$atau $\mathrm{pH}$ rendah dan adanya ion klorida yang merupakan ion agresif yang dapat menyerang lapisan pasif $\left(\mathrm{Fe}_{2} \mathrm{O}_{3}\right)$ atau besi (III) hidroksida sehingga logam baja akan mengalami korosi lubang (pitting corrosion) [1]. Untuk menghambat laju korosi baja karbon dalam lingkungan asam klorida perlu ditambahkan ekstrak daun cocor bebek yang mengandung bahan antioksidan yang bersifat seperti flavanoid dan tanin. Untuk menghasilkan ekstrak cocor bebek yang menggandung flavanoid dan tanin dilakukan proses ekstraksi menggunakan pelarut semi polar atau polar yaitu etilasetat, aseton, dan asam asetat. 
Penelitian tentang penggunaan ekstrak bahan alam sebagai inhibitor korosi di lingkungan asam klorida masih terbatas dan beberapa peneliti penggunaaan ekstrak bahan alam sebagai inhibitor di lingkungan asam pernah dilakukan seperti penggunaan ekstrak daun sirsak sebagai inhibitor di lingkungan $\mathrm{HCl}$ 1,0M yang menunjukkan bahwa ekstrak daun sirsak efektif menginhibisi baja karbon dengan efisiensi 93,68\% pada konsentrasi 6000 ppm selama 120 jam penelitian mengenai ekstrak bahan alam sebagai inhibitor korosi dengan penambahan inhibitor alam (getah pinus, gambir, ekstrak tembakau dan ekstrak kopi) dapat mengurangi laju korosi besi dalam larutan air laut. Inhibitor alam yang dapat mengurangi laju korosi paling baik adalah getah pinus yang dapat menurunkan laju korosi sebesar $87,22 \%$ pada rentang suhu $29-37^{\circ} \mathrm{C}$, dan melalui penelitian yang dilakukan oleh Saputra (2017) menggunakan pelarut metanol, nheksan, dan etilasetat menunnjukkan ekstrak menggunakan pelarut etilasetat mempunyai kemampuan untuk menurunkan laju korosi baja karbon di lingkungan $\mathrm{NaCl} 3,5 \%$ [3]. Hal ini disebabkan etil asetat mempunyai kepolaran lebih tinggi dibandingkan dengan n-heksana.

Berdasarkan hal tersebut, melalui penelitian terapan ini pengembangan pemanfaatan ekstrak daun cocor bebek menggunakan pelarut yang lebih bersifat semi polar dan polar yaitu metanol, etil asetat, aseton, dan asam asetat 5\%. Pemilihan ke empat pelarut tersebut disebabkan pelarut tersebut mudah diperoleh di pasaran, dan diharapkan mampu mengekstrak senyawa polar yang terkandung dalam daun cocor bebek, serta akan mampu untuk menginhibisi baja karbon di lingkungan yang korosif khususnya di lingkungan asam klorida.

\section{Bahan dan Metode}

Instumen pada penelitian ini adalah alat ekstraksi yang meliputi maserator untuk memperoleh ekstrak daun tumbuhan Cocor Bebek (K.pinnata), alat-alat gelas, rotary evaporator untuk menguapkan pelarut, sehingga didapatkan ekstrak kental daun tumbuhan Cocor Bebek (K. pinnata), penyangga, peralatan untuk uji laju korosi, dan elektroda standar untuk mengukur potensial logam, serta alat untuk analisis ekstrak

Bahan yang akan digunakan dalam penelitian ini adalah: daun tumbuhan Cocor Bebek (K. pinnata), pelarut-pelarut organik (aseton, etil asetat, dan metanol, dan asam asetat), akuades, $\mathrm{NaOH}, \mathrm{HCl}$, silika gel, kertas saring, kertas abrasif, dan logam baja karbon, larutan $\mathrm{FeCl}_{3} 1 \%$, dan larutan $\mathrm{NaCl}$ yang akan dijadikan media korosi.

Tahap pertama yaitu merupakan tahapan pembuatan ekstrak daun cocor bebek dengan melakukan tahapan pengancuran daun cocor bebek menjadi bubur, proses maserasi menggunakan metanol dengan rasio umpan : pelarut adalah 1:10 berat per volume selama 3 x 24 jam. Penyaringan dan filtratnya diuapkan menggunakan rotavapor sampai diperoleh pasta. Pasta yang dihasilkan dilakukan proses pemisahan ekstrak menggunakan berbagai pelarut organik seperti n-heksan. Etil asetat, aseton dan asam asetat.

Tahap kedua merupakan tahap pengujian ekstrak cocor bebek sebagai inhibitor korosi. Ekstrak cocor bebek dimanfaatkan sebagai inhibitor korosi dengan ditambahkan ke dalam larutan $\mathrm{HCl}$ yang telah disiapkan dan baja karbon yang telah dilakukan proses preparasi. Proses pengkorosian logam dilakukan dengan variasi konsentrasi ekstrak dari bervariasi pelarut (metanol, aseton, etil asetat, dan asam asetat 5\%) dan variasi konsentrasi larutan $\mathrm{HCl}(0,01 ; 0,05$; dan 0,1M). Berdasarkan hasil laju korosidari pengaruh ekstrak daun cocor bebek yang menunjukkan penurunan laju korosi terendah, selanjutnya dilakukan variasi waktu pengkorosian dengan penambahan 800 ppm ekstrak daun cocor bebek dari ekstrak pelarut tersebut. Selama pengkorosian logam, potensial logam dan $\mathrm{pH}$ larutan untuk melihat perubahan yang terjadi. Selanjutnya produk korosi dibersihkan dalam larutan $\mathrm{NaOH} 10 \%$ pada suhu $70^{\circ} \mathrm{C}$ selama 10 menit, dikeringkan dan ditimbang, sehingga diperoleh selisih berat yang akhirnya dapat dihitung laju korosinya. Data pengukuran dan hasil perhitungan laju korosi disajikan pada tabel atau grafik.

\section{Hasil dan Pembahasan}

Proses ekstraksi daun cocor bebek menggunakan pelarut metanol dan 
menggunakan metode maserasi yang dilakukan selama 3×24 jam. Hasil maserasi merupakan larutan atau fitrat yang terlah dilakukan proses filtrasi, yang akhirnya dilakukan proses pemekatan menggunakan metode destilasi. Proses destilasi bertujuan untuk menguapkan pelarut, sehingga pelarut dapat dimanfaatkan kembali. Hasil proses destilasi merupakan residu atau larutan pekat yang tetap tinggal di dalam reaktor yang hasilnya ditunjukkan pada Gambar 1 .

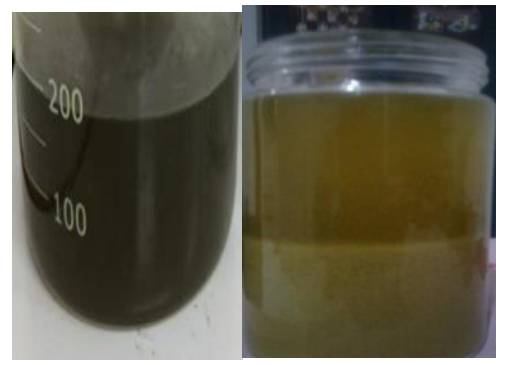

Gambar 1. Hasil maserasi menggunakan metanol

Gambar 1 menunjukkan larutan pekat berwarna hijau yang masih bercampur dengan hijau daun dan untuk menghilangkan zat hijau daun dilakukan ekstraksi cair-cair menggunakan pelarut heksana, dilanjutkan dengan pelarutan aseton, etil asetat, asam asetat 5\%. Hasil ekstraksi cair-cair menggunakan pelarut heksana di dalam corong pemisah membentuk dua (2) lapisan yang ditunjukkan pada Gambar 2a. dan hasil rafinatnya ditunjukkan pada $2 \mathrm{~b}$ berikut

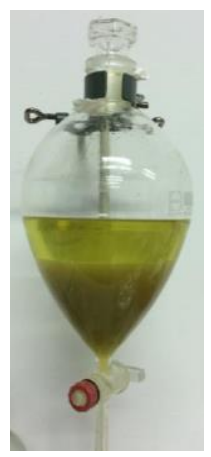

A

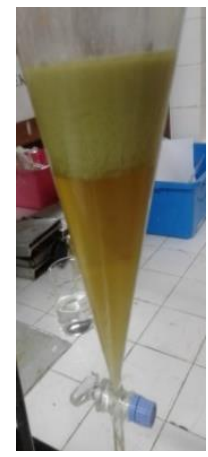

B

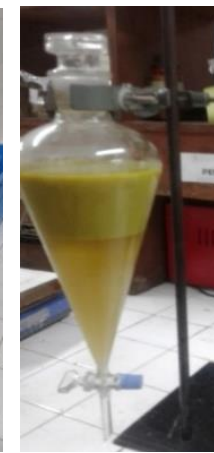

C

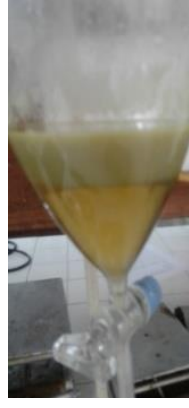

D

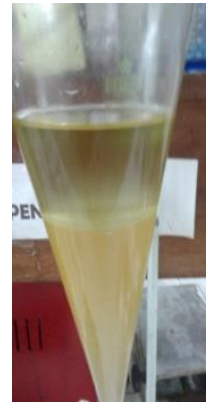

$\mathbf{E}$
Gambar 2. Ekstraksi cair-cair A. n-heksana, B.etil asetat, C.aseton, D. metanol, E. asam asetat 5\%)

Gambar 2 menunjukkan bahwa adanya dua lapisan yang merupakan ekstrak yang mengandung senyawa non polar larut dalam pelarut heksana yang bersifat non polar dan rafinat yang mengandung senyawa semipolar dan polar. Rafinat ini diekstraksi selanjutnya menggunakan pelarut etil asetat, asam asetat $5 \%$, dan aseton yang bersifat semipolar. Hal ini bertujuan untuk mengambil senyawa antioksidan yang bersifat semipolar yang dapat larut dalam pelarut semipolar pula [6].

\section{Analisis Ekstrak Daun Cocor Bebek}

Senyawa antioksidan yang terkandung dalam ekstrak daun cocor bebek antara lain adalah senyawa alkaloid, flavonoid, saponin, tanin, steroid atau triterpenoid [7, 8]. Senyawa tersebut mempunyai komposisi atom oksigen dan nitrogen yang masih memiliki sepasang elektron bebas. Dengan adanya sepasang elektron bebas ini pada atom oksigen atau nitrogen mempunyai kecenderungan akan tertarik ke permukaan logam membentuk ikatan kovalen koordinasi yang akhirnya mampu melapisi permukaan logam dengan proses adsorpsi [9]. Reaksi antara senyawa antioksidan seperti flavanoid dengan larutan $\mathrm{FeCl}_{3}$-_(adanya ion $\mathrm{Fe}^{3+}$ ) membentuk larutan yang berwarna hijau kehitaman seperti ditunjukkan pada hasil percobaan Gambar 3 [10]. 


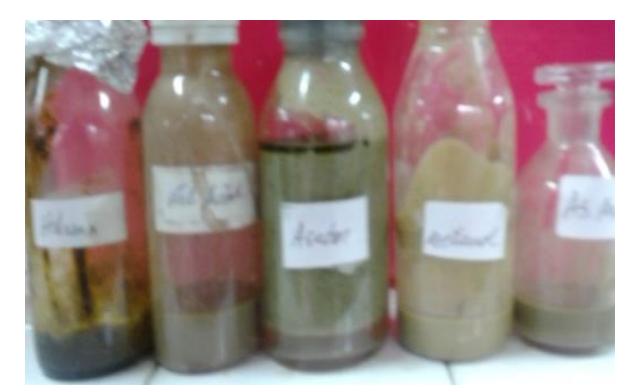

A

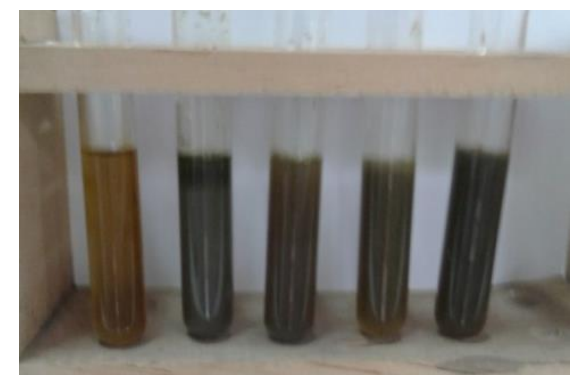

B

Gambar 3. A. Produk ekstrak ; B. Uji ekstrak dalam larutan $\mathrm{FeCl}_{3}$ 1\%

Gambar 3 yang ditunjukkan bahwa ekstrak daun cocor bebek yang ditambah larutan $\mathrm{FeCl}_{3} \quad 1 \%$ warna hijau kehitaman (Gambar 3b) daripada warna ekstrak yang belum diberikan larutan $\mathrm{FeCl}_{3}$ 1\% (gambar 3a). Hal tersebut menunjukkan bahwa ekstrak mengandung antioksidan yaitu flavanoid yang terkondensasi akibat reaksinya dengan ion logam $\mathrm{Fe}^{3+}$ membentuk senyawa kompleks dengan ikatan kimia kovalen koordinasi [9], sedangkan yang tidak mengandung antioksidan tetap berwarna hijau seperti yang ditunjukkan pada ekstrak hasil pelarut heksana. Warna tingkat kehitaman pada ekstrak menunjukkan tingkat kadar antioksidan seperti yang ditunjukkan pada ekstrak hasil ekstraksi menggunakan pelarut aseton. Ini menunjukkan bahwa ekstrak mengandung antioksidan yang bersifat semipolar yang ditunjukkan oleh tingkat kepolaran aseton adalah 5,4 [6].

Berdasarkan analisis kuantitatif ekstrak daun cocor bebek dalam variasi sifat kepolaran pelarut menggunakan alat spektrofotometer dengan panjang gelombang $511 \mathrm{~nm}$ ditunjukkan pada Gambar 4. berikut.

Kandungan flavanoid dalam ekstrak daun cocor bebek dihasilkan menggunakan pelarut aseton menunjukkan hasil paling tinggi, karena aseton merupakan pelarut yang bersifat semipolar dengan angkat tingkat kepolarannya 5,4 dibandingkan N-heksana yang bersifat nonpolar dan kandungan flavanoidnya tidak terdeteksi,tingkat kepolaran pelarut metanol 6,6 dan asam asetat 6,2 lebih bersifat polar [6]. Hasil tersebut juga diperkuat oleh hasil kualitatif ekstrak ditambah larutan $\mathrm{FeCl}_{3} 1 \%$ menunjukkan warna hijau kehitaman yang membuktikan adanya flavanoid (gambar 3b).' Proses ekstraksi daun cocor bebek menggunakan pelarut metanol dan menggunakan metode maserasi yang dilakukan selama 3x24 jam. Hasil maserasi merupakan larutan atau fitrat yang terlah dilakukan proses filtrasi, yang akhirnya dilakukan proses pemekatan menggunakan metode destilasi. Proses destilasi bertujuan untuk menguapkan pelarut, sehingga pelarut dapat dimanfaatkan kembali.

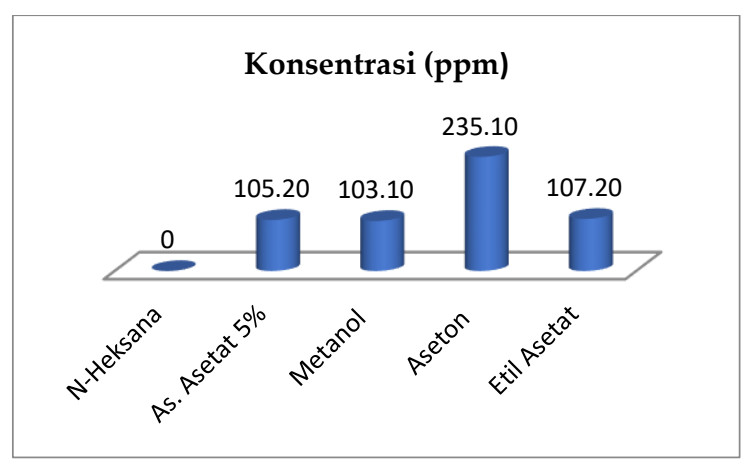

Gambar 4. Kandungan flavanoid dalam ekstrak daun cocor bebek

\section{Pengaruh Konsentrasi Ekstrak}

Konsentrasi ekstrak daun cocor bebek bervariasi di dalam larutan $\mathrm{HCl}$ 0,1M,0,05M,0,01M direndam logam baja karbon pada waktu 2 hari menunjukkan hasil seperti pada Gambar 5.

Gambar 5 menunjukkan bahwa laju korosi baja karbon dalam larutan $\mathrm{HCl} 0,1 \mathrm{M}$; 0,05M; 0,01M dengan penambahan ekstrak daun cocor bebek mengalami penurunan seiring dengan peningkatan konsentrasi ekstrak dan mencapai penurunan terendah pada penambahan ekstrak dalam pelarut aseton sekitar 200 ppm dengan laju korosi 42,18 mpy dalam larutan $\mathrm{HCl} 0,1 \mathrm{M}$ dan pada peningkatan konsentrasi ekstrak terdapat penurunan laju tidak menunjukkan penurunan laju korosi yang signifikan. Untuk larutan $\mathrm{HCl}$ 0,05M dan 0,01m konsentrasi menunjukkan penurunan laju korosi sampai pada penambahan ekstrak 1500 ppm. Hasil ekstrak menggunakan pelarut 
aseton menunjukkan laju korosi baja karbon dalam larutan $\mathrm{HCl}$ 0,1M; 0,05M; dan 0,01M lebih rendah dibandingkan hasil ekstrak dengan pelarut lain ( etil asetat, metanol, dan asam asetat $5 \%$ ). Hal ini disebabkan aseton merupakan pelarut bersifat lebih semipolar dan mempunyai kepolaran lebih tinggi daripada etil asetat dan n-heksana dan lebih rendah daripada metanol dan asam aseat yang mampu melarutkan senyawa antioksidan yang terdapat dalam ekstrak daun cocor bebek yang juga bersifat semipolar [6, 9]. Hal tersebut disebabkan juga hasil esktrak menggunakan pelarut aseton menunjukkan jumlah kandungan antioksidan dalam ekstrak paling tinggi yang ditunjukkan warna hijau kehitaman paling menyolok (lihat Gambar 3b) melalui analisis kualitatif dan Gambar 4 hasil analisis kuantitatif menggunakan spektrofotometer UV-Vis pada panjang gelombang $511 \mathrm{~nm}$.
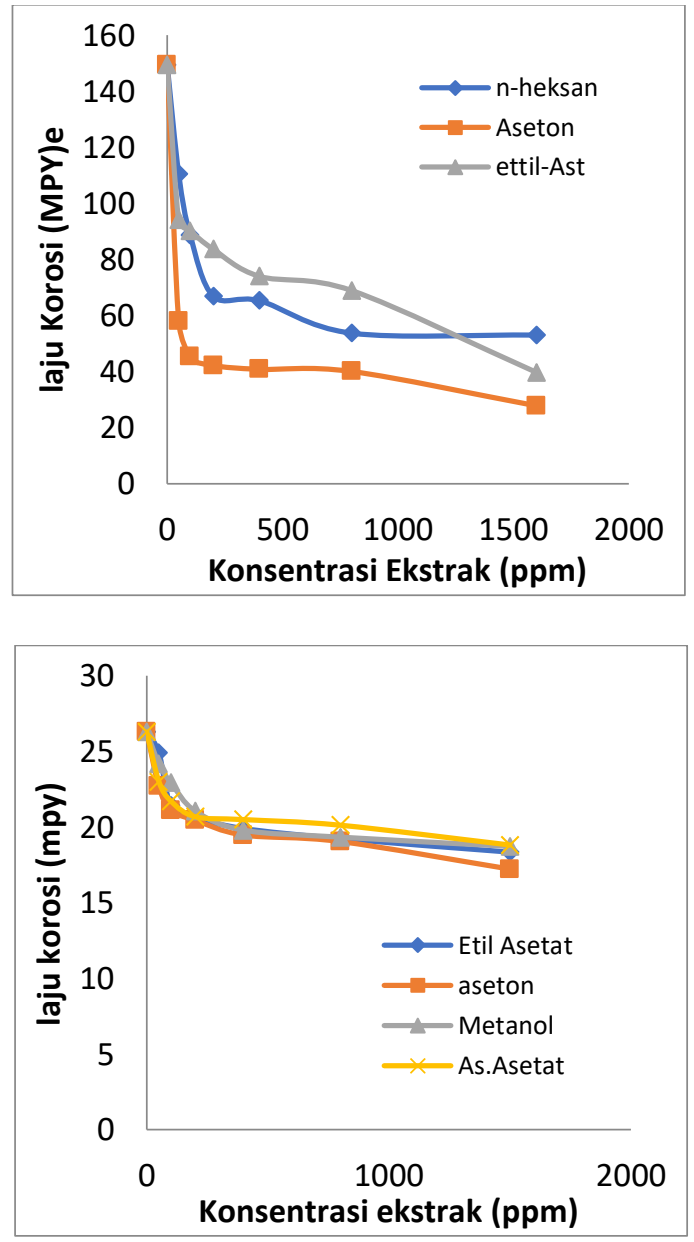

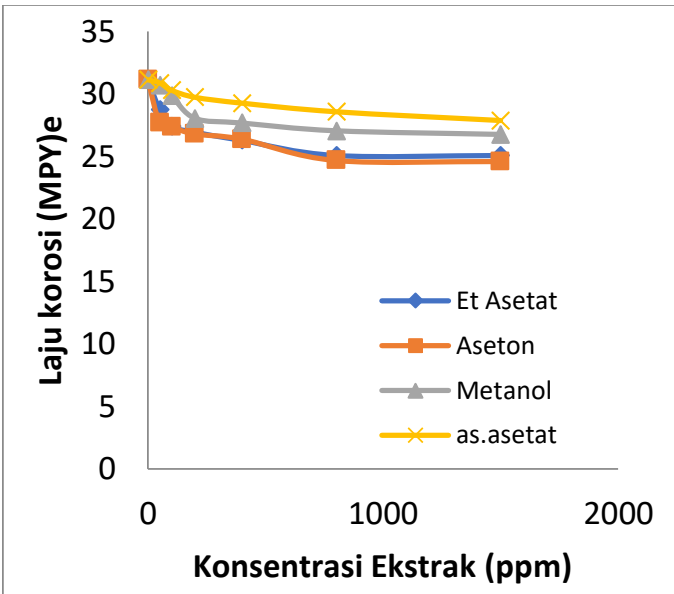

Gambar 5. Pengaruh Konsentrasi Ekstrak terhadap Laju Korosi Baja Karbon

Jika berdasarkan efisiensi inhibisi ekstrak juga ditunjukkan bahwa ekstrak yang dihasilkan menggunakan pelarut aseton mempunyai efisiensi lebih tinggi dibandingkan menggunakan pelarut lain seperti ditunjukkan pada Tabel 1.

Tabel 1. Efisiensi Inhibisi Ekstrak

\begin{tabular}{ccccc}
\hline $\begin{array}{c}\text { Konsentrasi } \\
\text { ekstrak } \\
(\mathrm{ppm})\end{array}$ & $\begin{array}{c}\text { Etl } \\
\text { Asetat }\end{array}$ & Aseton & Metanol & $\begin{array}{l}\text { as. } \\
\text { Asettat }\end{array}$ \\
\hline 0 & 0 & 0 & 0 & 0 \\
\hline 50 & 5,14 & 13,66 & 7,99 & 12,44 \\
\hline 100 & 18,46 & 19,71 & 12,79 & 17,39 \\
\hline 200 & 21,5 & 22,18 & 19,9 & 21,31 \\
\hline 400 & 24,28 & 25,91 & 24,7 & 22,03 \\
\hline 800 & 26,83 & 27,55 & 26,45 & 23,44 \\
\hline 1500 & 30,21 & 34,47 & 28,77 & 18,81 \\
\hline
\end{tabular}

Sifat inhibisi ekstrak cocor bebek menggunakan ke empat pelarut ditunjukkan bahwa sifat inhibisi ekstrak yang dihasilkan menggunakan pelarut aseton menghasilkan sifat inhibisi yang lebih baik dibandingkan ekstrak dari menggunakan pelarut lainnya (etil asetat, metanol, dan asam asetat $5 \%$ ) meskipun masih menunjukkan efisiensi inhibisi masih dibawah $50 \%$, tetapi peningkatan konsentrasi ekstrak yang ditambahkan ke dalam media larutan $\mathrm{HCl}$ menunjukkan peningkatan efisiensi inhibisinya.

\section{Kesimpulan}

Dari penelitian yang telah dilakukan dapat disimpulkan bahwa sifat inhibisi ekstrak 
cocor bebek menggunakan pelarut aseton menghasilkan sifat inhibisi yang lebih baik dibandingkan ekstrak dari menggunakan pelarut lainnya (etil asetat, metanol, dan asam asetat 5\%) meskipun masih menunjukkan efisiensi inhibisi masih dibawah 50\%, tetapi peningkatan konsentrasi ekstrak yang ditambahkan ke dalam media larutan $\mathrm{HCl}$ menunjukkan peningkatan efisiensi inhibisinya.

\section{Daftar Pustaka}

1. Asdim, A., Penghambatan Reaksi Korosi Baja Dengan Menggunakan Ekstrak Kulit Buah Manggis (Garcinia Mangostana L) Sebagai Inhibitor Dalam Larutan Garam. GRADIEN: Jurnal Ilmiah MIPA 2008, 4, (1), 304-307.

2. Jones, D. A., Principles and prevention of corrosion. Macmillan: 1992.

3. Haryono, G.; Sugiarto, B.; Farid, H.; Tanoto, Y. In Ekstrak bahan alam sebagai inhibitor korosi, Prosiding Seminar Nasional Teknik Kimia “Kejuangan"(1), 2010; pp 16.

4. Rahmawati, F., Elektrokimia: Transformasi Energi Kimia-Listrik. Yogyakarta: Graha Ilmu 2013.

5. Saputra, T. R. Senyawa Flavonoid Kuersetin dan Kaempferol dari Daun Kalanchoe pinnata. Universitas Padjadjaran, Jatinangor, 2014.

6. Baki, G.; Alexander, K. S., Introduction to cosmetic formulation and technology. John Wiley \& Sons: 2015.

7. Malsaidi, M. Uji Efek Penurunan Kadar Asam Urat dari Ekstrak Etanol Daun Cocor Bebek (Bryopyillum pinnatum (Lam.) Oken) pada Mencit Jantan. Universitas Sumatra Utara, Medan, 2015.

8. Saputra, T. R.; Ngatin, A., Extract of Cocor Bebek (Kalanchoe Pinnata) as a Corrosion Inhibitor. Jurnal Bahan Alam Terbarukan 2017, 6, (2), 112-116.

9. Latifah, L. Identifikasi golongan senyawa flavonoid dan uji aktivitas antioksidan pada ekstrak rimpang kencur Kaemferia galanga L. dengan metode dpph $(1,1-$ difenil-2-pikrilhidrazil). Universitas Islam Negeri Maulana Malik Ibrahim, 2015.
10. Ashari, A. Uji Inhibisi korosi pada baja lunak menggunakan ekstrak senyawa tanin dari daun ketapang (Terminalia catappa L) dalam larutan garam. Universitas Lampung, Lampung, 2013. 